\title{
Detection of E. coli O157:H7 in Meat Using Polymerase Chain Reaction Method and Culture Method
}

\author{
Mozhgan Bahadoripour, Mohammad Hassan Jahandar* \\ Department of Agriculture, Bam Branch, Islamic Azad University, Bam, Iran
}

*Correspondence to Mohammad Hassan Jahandar Tel: +989155005780; Email: Jahandar@iaubam.ac.ir

Received October 31, 2018 Accepted March 5, 2019 Published online September 30, 2019

\begin{abstract}
Introduction: Escherichia coli $\mathrm{O} 157: \mathrm{H} 7$, as a pathogenic agent, can be transmitted through the foods including meat, meat products, dairy products, vegetables and water. The World Health Organization has recommended that all countries in the world, especially developing countries, should consider the investigation of $E$. coli $\mathrm{O} 157: \mathrm{H} 7$ as a research priority. The aim of this study was to determine the frequency of $E$. coli O157:H7 in meat of cow, sheep, goat, and camel in Kerman province of Iran using culture and polymerase chain reaction (PCR) methods. Methods: In this study, 280 meat samples consisting of sheep (90 specimens), cow (80 specimens), goat (60 specimens) and camel (50 specimens) meats were randomly separated from carcasses from April to July 2018. After the sampling, microbial culture was performed on the samples. Then, suspected E. coli O157:H7 colonies were evaluated by PCR assay.

Results: Out of the 280 samples, 73 samples (26\%) were contaminated with E. coli. based on bacteriological tests, and 28 samples were identified as suspected E. coli O157:H7 serotype based on the lack of sorbitol fermentation. Subsequently, sorbitol-negative samples were tested by PCR procedure using specific primers. The results revealed that out of 28 cases, 21 cases (7.5\%) were E. coli O157: H7.

Conclusion: As can be deduced from the observations of this study, to detect the E. coli O157, PCR as an accurate, fast, and reliable procedure can be used along with the culture method. Keywords: E. coli O157:H7, PCR, Culture, Meat contamination
\end{abstract}

Please cite this article as follows: Bahadoripour $\mathrm{M}$, Jahandar $\mathrm{MH}$. Detection of $E$. coli O157:H7 in meat using polymerase chain reaction method and culture method. Int J Basic Sci Med. 2019;4(3):102107. doi:10.15171/ ijbms.2019.19.

\section{Introduction}

Meat is one of the most important sources of protein. It contains valuable proteins, essential amino acids, minerals (especially iron and zinc), and vitamins, which make it one of the most valuable foods. ${ }^{1}$ The main source of meat contamination is livestock. Carcass contamination can be caused by microbial diseases of the livestock during slaughter or due to the non-compliance with the sanitation procedures during the slaughter process. $^{2}$ Wool, skin, moist parts of the body such as muzzle, mouth, eyelid, ear, anus, external genitalia, and breast are contaminated with various types of microorganisms which cause infection and food poisoning. ${ }^{3}$ In addition, there are some dangerous intestinal microbes in intestinal tract such as Escherichia coli. The most common serotype of this bacterium is O157:H7. In recent years, Escherichia coli O157:H7 caused epidemics in some parts of the world and has attracted the attention of researchers and health care practitioners. Escherichia coli O157:H7 is considered as the most important serotype of enterohemorrhagic Escherichia coli (EHEC) which plays an important role in the incidence of Ulcerative colitis, Thrombotic thrombocytopenic purpura, and Hemolytic uremic syndrome. ${ }^{4}$ Hemolytic uremic syndrome has occurred in $2 \%-7 \%$ of patients and caused death in 3\%-5\% of cases. ${ }^{5}$ The World Health Organization (WHO) has recommended that all countries in the world, especially developing countries, should consider the investigation of E. coli $\mathrm{O} 157: \mathrm{H} 7$ as a research priority.

The isolation and identification of this bacterium using the conventional methods of microbiology are major challenges. Typically, MacConkey Sorbitol agar or antibody-based methods such as serological

(c) 2019 The Author(s); Published by Zabol University of Medical Sciences. This is an open-access article distributed under the terms of the Creative Commons Attribution License (http://creativecommons.org/licenses/by/4.0), which permits unrestricted use, distribution, and reproduction in any medium, provided the original work is properly cited. 
tests are used to detect this bacterium in diagnostic laboratories. However, mistakes may occur in the final identification of the pathogen due to some defects in these methods. For example, sorbitol fermentation may fail to detect some strains of E. coli O157, ${ }^{6}$ or identification by serological methods may not be performed due to losing their outer membrane antigen through the mutation or because of cross-reactivity with other bacteria. ${ }^{7}$ It should be noted that neither of these methods is capable to identify the toxin-producing strains. ${ }^{8}$ Therefore, using the molecular techniques for identifying E. coli O157:H7 is essential. In E. coli O157 strain, O157 antigen is coded by a 12-gene cluster. Out of these genes, 6 genes are responsible for the sugar-base biosynthesis, 4 genes are responsible for transferring the sugar, and the 2 remaining genes encode the flippase protein and the $\mathrm{O}$ antigen polymerase. The protein which is encoded by the $r f b E$ gene is located in the group of proteins involved in sugarfree biosynthesis and plays a major role in the synthesis of LPS bacteria. ${ }^{9,10}$ As soon as the bacterium binds to the intestinal mucosa, this pathogen begins to grow and secrete a toxin which is called Shiga toxin. Shiga toxin (Stx) is an important pathogenic factor in Shiga toxin producing E. coli (STEC), and Stx 2 and Stx 1 are two kinds of this toxin. ${ }^{1,12}$ Stx 2 toxin is 1000 times more toxic for endothelial cells of the renal artery, compared to Stx $1 .^{12}$ In this study, detection of $E$. coli $\mathrm{O} 157: \mathrm{H} 7$ by polymerase chain reaction (PCR) procedure was performed using two specific primers for the detection of $s t x 2 b$ and $r f b E$ genes. The aim of this study was to determine the prevalence of E. coli O157:H7 infection in Kerman province using two methods of PCR and culture.

\section{Materials and Methods}

A total of 280 meat samples including 90 sheep, 80 cow, 60 goat and 50 camel specimens were prepared randomly from Kerman, Iran, from April to July 2018, according to the standard principles of sanitation. The samples were transferred to the laboratory on ice. Detection of E. coli O157:H7 and the isolation steps were carried out within 12 hours after sampling.

\section{Microbial Culture}

To find E. coli O157:H7 in the test samples, the Tryptic Soy Broth (Merck, Germany) containing $20 \mathrm{mg} / \mathrm{L}$ novobiocin was added to $10 \mathrm{~g}$ of homogenized tissue of each sample and incubated for $18-24$ hours at $37^{\circ} \mathrm{C}$. Then, $100 \mu \mathrm{L}$ of them was again incubated in Eosin Methylene Blue medium and MacConkey Sorbitol (Merck, Germany) containing cefixime and potassium tellurite for 24 hours at $37^{\circ} \mathrm{C}$. In next step, the suspicious colonies of E. coli were traced using the Triple Sugar Iron (TSI) medium, IMViC test, and fermentation of sorbitol. ${ }^{13}$

\section{DNA Extraction}

Sorbitol-negative colonies of E. coli O157:H7 were selected for further investigation using the PCR procedure. For this purpose, DNA extraction was accomplished using the DNA extraction kit (Sinagen, Iran) based on the protocol provided by the company. The qualification and quantification of extracted DNA were examined by $1 \%$ agarose gel and Nanodrop device (Thermo Scientific, USA), respectively. The extracted DNA was stored at $-20^{\circ} \mathrm{C}$ for PCR procedure.

\section{PCR Procedure}

The st $x 2 b$ and $r f b E$ genes with 300 and 126 bp, respectively, were amplified using one pair of specific primers (Table 1). PCR was carried out in $25 \mu \mathrm{L}$ final volume containing approximately $50-100 \mathrm{ng}$ template DNA, $2.5 \mu \mathrm{L}$ of $10 \times$ PCR buffer, $2 \mu \mathrm{L}$ dNTPs $(2.5 \mathrm{mM}), 2 \mu \mathrm{L} \mathrm{MgCl}_{2}(10$ $\mathrm{mM}), 1.5 \mu \mathrm{L}$ of mix primer $(5 \mathrm{pmol} / \mu \mathrm{L}), 0.125 \mathrm{U} / \mu \mathrm{L}$ of X' Taq DNA polymerase (Takara, Japan), and distilled deionized water up to a volume of $25 \mu \mathrm{L}$. To perform the PCR reaction, thermal cycling was carried out in AB 2720 thermal cycler (Applied Biosystem, USA) using a specific schedule with pre-denaturation at $95^{\circ} \mathrm{C}$ for 5 minutes, and 30 cycles of denaturation at $95^{\circ} \mathrm{C}$ for 30 seconds, annealing at $59^{\circ} \mathrm{C}$ and $62^{\circ} \mathrm{C}$ for 30 seconds for identifying $s t x 2 b$ and $r f b E$ genes, respectively, and extension at $72^{\circ} \mathrm{C}$ for 30 seconds. The final extension step was completed at $72^{\circ} \mathrm{C}$ for 5 minutes. ${ }^{14}$ PCR products were checked by electrophoresis on $1.5 \%$ agarose gel in $1 \mathrm{X}$ TBE buffer with a $1 \mathrm{~kb}$ DNA size marker (Fermentas, Germany). Virtualization of PCR products was conducted using gel documentation system (BioRad, USA) (Figure 1).

\section{Results}

Microbial Culture and PCR Procedure

Of the 280 samples, 73 samples $(26.07 \%$ ) were determined to be contaminated with $E$. coli based on bacteriological tests and 28 samples (10\%) were identified as suspected E. coli O157:H7 serotype based on the lack of sorbitol fermentation. Subsequently, sorbitol-negative samples

Table 1. Specific Primers for Detection of E. coli O157:H7 Using PCR

\begin{tabular}{lccc}
\hline Virulence Factor & Target Gene & Primer & Primer Sequences (5'-3') \\
\hline \multirow{2}{*}{$r f b E$} & $r f b E$ & $r f b E-\mathrm{F}$ & TCAAAAGGAAACTATATTCAGAAGTTTGA \\
& & $r f b E-\mathrm{R}$ & CGATATACCTAACGCTAACAAAGCTAA \\
Shiga toxin 2 subunit $B$ & $s t \times 2 b$ & $s t \times 2 b-F$ & TATACGATGACACCGGAAGAAG \\
& & $s t \times 2 b-R$ & CCTGCGATTCAGAAAAGCAGC \\
\hline
\end{tabular}




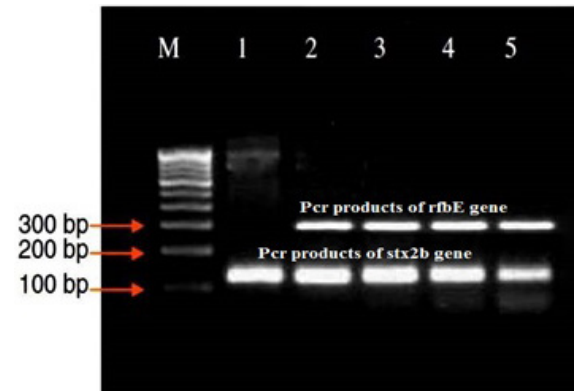

Figure 1. PCR Products of $s t \times 2 b$ Gene (126 bp) and rfbE Gene (300 bp).

were selected for confirmation of the E. coli O157:H7 by PCR process and specific primers. The results of this study showed that out of 28 suspected cases, 21 cases (7.5\%) were found to be E. coli $\mathrm{O} 157: \mathrm{H} 7$ and E. coli $\mathrm{O} 157: \mathrm{H} 7$ was not confirmed in 7 cases. The contamination frequency (out of 280 samples) of the cow, sheep, goat and camel meats were observed to be $2.14 \%, 3.57 \%, 1.42 \%$, and $0.36 \%$, respectively (Table 2 ). As it is noted, the incidence of infection in the warmer months of the year (June and July) was higher compared to colder months in both methods based on PCR and lack of sorbitol fermentation (Table 3).

\section{Discussion}

Escherichia coli O157:H7 is considered as the most important serotype of the enterohemorrhagic E. coli and plays an important role in the incidence of ulcerative colitis, thrombotic thrombocytopenic purpura, and hemolytic uremic syndrome. ${ }^{4}$ Hemolytic uremic syndrome occurs in $2 \%-7 \%$ of patients and results in death in $3 \%-5 \%$ of cases. ${ }^{5}$ Although it has been proven that this bacterium is found in all geographical areas and can be isolated from different kinds of foods, its occurrence varies in different regions depending on the type of food, the sampling season and the methods of isolation. ${ }^{15,16}$

Ruminants and their products are the main source of $E$. coli O157:H7 infection. The results of conducted research on camel meat in Iran showed that E. coli O157:H7 was detected in $1.1 \%$ of 94 camel carcass samples. ${ }^{17}$ However, in a study on camel stool which was conducted in the UAE, no E. coli O157:H7 was observed. ${ }^{18}$ In another research in 5 countries of East Africa on faecal and serum samples of 400 camels with STEC or anti-STX antibodies, no E. coli O157:H7 contamination was reported, ${ }^{19}$ which is not in accordance with the results of this study. The research results of Haji et al in 2011 showed that the prevalence of E. coli O157:H7 in 75 samples of camel meat was $1.7 \%,{ }^{20}$ using the PCR procedure. Rahimi et al in 2012 also reported that out of 50 camel meat samples, the frequency of $E$. coli $\mathrm{O} 157: \mathrm{H} 7$ was about $2 \%$ using PCR, ${ }^{17}$ which contradicted the results of the present research. This discrepancy may be due to sampling time, sampling

Table 2. Frequency of $E$. coli O157: H7 Contamination in Different Meats

\begin{tabular}{|c|c|c|c|c|c|c|c|}
\hline \multirow[t]{2}{*}{ Animal } & \multirow[t]{2}{*}{$\begin{array}{c}\text { No. of } \\
\text { Samples }\end{array}$} & \multicolumn{2}{|c|}{$\begin{array}{c}\text { Subtracting the Positive } \\
\text { Samples Based on the PCR } \\
\text { Results of } 2 \text { Genes }\end{array}$} & \multirow{2}{*}{$\begin{array}{l}\text { Positive Samples for } \\
\text { E. coli O157:H7 (\% } \\
\text { out of 280 Samples) } \\
\text { PCR }\end{array}$} & \multirow{2}{*}{$\begin{array}{c}\text { Samples Contaminated } \\
\text { With E. coli Based on } \\
\text { Culture Method (\% out of } \\
280 \text { Samples) }\end{array}$} & \multirow{2}{*}{$\begin{array}{c}\text { Samples Positive for } E \text {. } \\
\text { coli O157:H7 (\% Per } \\
\text { Each Animal Grope) }\end{array}$} & \multirow{2}{*}{$\begin{array}{c}\text { Samples Contaminated } \\
\text { With E. coli Based on } \\
\text { Culture Method (\% Per } \\
\text { Each Animal Grope) }\end{array}$} \\
\hline & & stx2b Gene & rfbE Gene & & & & \\
\hline Cow & 80 & 4 & 2 & $6(2.14 \%)$ & $22(7.85 \%)$ & $6(7.5 \%)$ & $22(27.5 \%)$ \\
\hline Sheep & 90 & 6 & 4 & $10(3.57 \%)$ & $27(9.64 \%)$ & $10(11.11 \%)$ & $27(30 \%)$ \\
\hline Goat & 60 & 3 & 1 & $4(1.42 \%)$ & $16(5.71 \%)$ & $4(6.66 \%)$ & $16(26.66 \%)$ \\
\hline Camel & 50 & 1 & 0 & $1(0.36 \%)$ & $8(2.85 \%)$ & $1(1.66 \%)$ & $8(16 \%)$ \\
\hline Total & 280 & 14 & 7 & $21(7.5 \%)$ & $73(26.07 \%)$ & 21 & 73 \\
\hline
\end{tabular}

The difference in the data shown in columns 5 and 6 compared to the next two columns 7 and 8 is \% of positive samples out of total (280) samples and \% of positive samples within each animal group, respectively.

Table 3. Frequency of E. coli O157: H7 Contamination in Meat, in Different Months of Sampling

\begin{tabular}{|c|c|c|c|c|c|c|}
\hline Month & $\begin{array}{l}\text { No. of } \\
\text { Samples }\end{array}$ & $\begin{array}{c}\text { Samples } \\
\text { Contaminated With } \\
\text { E. coli O157:H7 } \\
\text { Based on PCR }\end{array}$ & $\begin{array}{l}\text { Samples Suspicious to } E \text {. coli } \\
\text { O157:H7 Based on Lack of } \\
\text { Sorbitol Fermentation (\% out } \\
\text { of } 280 \text { Samples) }\end{array}$ & $\begin{array}{l}\text { Samples Contaminated } \\
\text { With E. coli Based On } \\
\text { Culture Method (\% out } \\
\text { of } 280 \text { Samples) }\end{array}$ & $\begin{array}{l}\text { Samples Suspicious to } E \text {. coli } \\
\text { O157:H7 Based on lack of } \\
\text { Sorbitol Fermentation (\% Per } \\
\text { Each Month) }\end{array}$ & $\begin{array}{c}\text { Samples Contaminated } \\
\text { With E. coli Based on } \\
\text { Culture Method (\% Per } \\
\text { Each Month) }\end{array}$ \\
\hline April & 65 & 1.07 & $5(1.78 \%)$ & $12(4.28 \%)$ & $5(7.69 \%)$ & $12(18.46 \%)$ \\
\hline May & 65 & 1.07 & $4(1.42 \%)$ & $14(5 \%)$ & $4(6.15 \%)$ & $14(21.535)$ \\
\hline June & 76 & 2.14 & $8(2.85 \%)$ & 25 (8.92\%) & $8(10.52 \%)$ & 25 (31.64\%) \\
\hline July & 74 & 3.21 & $11(3.92 \%)$ & $22(7.85 \%)$ & $11(14.685)$ & $22(29.72 \%)$ \\
\hline Total & 280 & 7.5 & $28(10 \%)$ & $73(26.05)$ & 28 & 73 \\
\hline
\end{tabular}

The difference in the data shown in columns 4 and 5 compared to the next two columns 6 and 7 is related to \% of suspicious samples based on lack of sorbitol fermentation out of total (280) samples and \% of contaminated samples based on lack of sorbitol within each month, respectively. 
method, number of samples, sex, and age of the studied animals.

Studies have shown that the prevalence of this pathogen in beef and its products is between $0 \%$ and $8.27 \% .^{16,21,22}$ Rahimi et al examined 203 carcasses of cows, of which $42.4 \%$ were positive for E. coli and 6.4\% showed E. coli O157:H7 infection, which was higher than the report of the present study. ${ }^{23}$ In a study on veal in an industrial slaughterhouse, it was found that slaughtered animals were contaminated with E. coli O157:H7, ranging from 0 to $8 \%{ }^{24}$ Tests for detection of E. coli O157:H7 are not carried out in slaughterhouses and factories in Iran; therefore, the possibility of contamination of meat products with this pathogen is increased. In another study, Hajian et al demonstrated that the prevalence of E. coli $\mathrm{O} 157: \mathrm{H} 7$ in beef was $2.2 \%$, which was lower than results of this study. ${ }^{20}$ Furthermore, researches stated that contamination of cow carcasses usually occurs directly and indirectly during slaughtering, transporting, peeling, discharging the viscous material, and transferring to refrigerator. ${ }^{25}$

Blanco et al reported that the rate of contamination with verotoxin-producing $E$. coli varies from 0 to $60 \%$ and the prevalence of $\mathrm{O} 157: \mathrm{H} 7$ has been estimated to be $5 \%$ in cows at the time of slaughter. ${ }^{26}$ Turkish scholars in 2006 reported that E. coli O157:H7 was isolated from 77 samples (13.6\%) of slaughtered cattle, 66 samples (11.7\%) of which belonged to the O157:H7 serotype and 11 samples (1.9\%) were non- motile strains (O157:NM) ${ }^{27}$ In a conducted study in Bangladesh in 2008, the researchers showed that $14.4 \%$ of buffalos $(n=174)$, $7.2 \%$ of cows $(n=139)$ and $9.1 \%$ of goats $(n=110)$ were infected with STEC O157:H7. ${ }^{28}$ Samples of the rectal contents were collected immediately after the animals were slaughtered..$^{28}$ The rate of contamination of beef with E. coli O157:H7 in Netherlands, England and the United States were $10.4 \%, 13.4 \%$, and $28 \%$, respectively, which were higher compared to the results obtained in this study. ${ }^{15,29,30}$ Moreover, the frequency of E. coli O157:H7 contamination in beef in this study was higher than the reported value in Ireland (0.6\%), Italy (6.3\%), Switzerland (3.2\%), and Argentina (3.8\%). ${ }^{16,31-33}$

Sheep, after the cattle, are considered as the second major ruminant in providing meat in Iran, and some researchers declared that the role of sheep as a reservoir of E. coli O157:H7 is the same as that of cattle. ${ }^{5,34}$ The rate of infection of lambs with this pathogen in Iran, Australia, the United States, Italy, and Egypt were reported to be $93.3 \%, 0.5 \%, 1.5 \%, 0.77 \%-1.7 \%$, and $4 \%$, respectively. A survey on 62 beef and 60 goat meats, using PCR process, demonstrated that the prevalence of E. coli O157:H7 was $4.8 \%$ and $1.7 \%$ for lamb and goat, respectively. ${ }^{17}$ Another study on 159 lambs showed that the prevalence of E. coli O157:H7 was 3.8\% using PCR method. ${ }^{35}$ In another study in Egypt, the prevalence of E. coli O157:H7 in lambs and goats were $2.5 \%$ and $2 \%$, respectively. ${ }^{36,37}$ The infection rates in lamb and goat meat in Italy were reported to be 7.3 and $0.7 \%$, respectively. ${ }^{38}$ Other researchers reported that the prevalence of E. coli $\mathrm{O} 157: \mathrm{H} 7$ was $1.2-5.5 \%$ in lambs in the United States ${ }^{21}$ and $0.3-1.5 \%$ in Australia. ${ }^{39,40}$ Differences in the prevalence of E. coli $\mathrm{O} 157: \mathrm{H} 7$ can be due to the sampling methods, the size of selected samples, and the method of isolation. ${ }^{29}$

In this study, the highest rate of contamination was found in summer, which is consistent with Hancock et al and Elder et al studies. ${ }^{30,41}$ The prevalence E. coli O157:H7 is typically low in winter and increases in the spring with the peak levels during summer. This is because the cold kills and reduces the load of E. coli O157:H7. ${ }^{42}$

An investigation was done on 145 feedlot cattle and 9 dairy cull cows in a slaughterhouse in Shiraz, Iran. E. coli O157:H7 was identified in cattle through detection of the Stx 2 gene using PCR procedure. The results showed that 14 cases out of 154 (9.65\%) feedlot cattle and in 1 cases out of $9(11.1 \%)$ dairy cattle were infected with $E$. coli O157:H7. ${ }^{24}$ In detection of the E. coli O157 and O157:H7 strains using Stx2 in Shiraz, Iran, E. coli O157:H7 was found in $6(3.92 \%)$ of 153 sheep, from which 5 sheep were $<2$ years old, highlighting the possible effect of age and differences in diets on gastrointestinal flora. ${ }^{43}$

In the present study, 28 samples (10\%) were identified as E. coli $\mathrm{O} 157: \mathrm{H} 7$ based on the lack of sorbitol fermentation. The results of PCR procedure demonstrated that out of the 28 samples, 21 cases were identified as E. coli O157:H7. These results confirmed the importance of molecular methods in detecting this pathogen. This method not only can save time but also is very cost-effective. Therefore, it is suggested as a superior procedure in isolating $E$. coli O157:H7 from foods. In this regard, previous researches from Iran declared that PCR procedure is a fast method to detect the E. coli O157:H7 in the pharmaceutical, food, and water industries. ${ }^{44}$ In another study in 2009 in Iran, researchers have proven that PCR-based methods are fast and reliable methods to detect and identify as few as 100 cells of E. coli O157:H7, Vibrio cholerae, and Salmonella typhimurium. ${ }^{45}$

The present study is the first report on the E. coli O157:H7 contamination rate in meat in Kerman, Iran and suggests that the consumption of semi-cooked meat (especially beef and lamb) may contribute to the transmission of this pathogen to humans. Therefore, the precise monitoring and observance of health principles during slaughtering, transportation, and maintenance processes can reduce the transmission rate. More studies are recommended in other regions of Iran.

\section{Ethical Approval}

This article does not contain any studies with animals performed by any of the authors

\section{Competing Interest}

The authors declare there is no conflicts of interest. 


\section{Acknowledgements}

This study was financially supported by Islamic Azad University of Bam Branch.

\section{References}

1. Pereira PM, Vicente AF. Meat nutritional composition and nutritive role in the human diet. Meat Sci. 2013;93(3):586592. doi:10.1016/j.meatsci.2012.09.018

2. McKenzie AI, Hathaway SC. The role and functionality of Veterinary Services in food safety throughout the food chain. Rev Sci Tech. 2006;25(2):837-848.

3. Friedberger F, Fröhner E. Pathology and Therapeutics of the Domestic Animals. Vol 2. WL Zuill; 1895.

4. Shapouri R, Rahnema M, Eghbalzadeh S. Prevalence of salmonella serotypes in poultry meat and egg and determine their antibiotic sensitivity in Zanjan city. Journal of Animal Physiology and Development. 2009;2(3):63-71.

5. Stampi S, Caprioli A, De Luca G, Quaglio P, Sacchetti R, Zanetti F. Detection of Escherichia coli O157 in bovine meat products in northern Italy. Int J Food Microbiol. 2004;90(3):257-262. doi:10.1016/s0168-1605(03)00308-8

6. Ojeda A, Prado V, Martinez J, et al. Sorbitol-negative phenotype among enterohemorrhagic Escherichia coli strains of different serotypes and from different sources. J Clin Microbiol. 1995;33(8):2199-2201.

7. Noveir MR, Dogan HB, Kadir Halkman A. A note on Escherichia coli O157:H7 serotype in Turkish meat products. Meat Sci. 2000;56(4):331-335. doi:10.1016/ S0309-1740(00)00058-9

8. Saeed AY, Ibrahim KS. Identification of Escherichia coli O157 in sheep and goats using PCR technique. IOSR Journal of Agriculture and Veterinary Science. 2013;6(2):30-32.

9. Tarr PI, Schoening LM, Yea YL, Ward TR, Jelacic S, Whittam TS. Acquisition of the rfb-gnd cluster in evolution of Escherichia coli O55 and O157. J Bacteriol. 2000;182(21):6183-6191. doi:10.1128/jb.182.21.61836191.2000

10. Maurer JJ, Schmidt D, Petrosko P, Sanchez S, Bolton L, Lee MD. Development of primers to O-antigen biosynthesis genes for specific detection of Escherichia coli $\mathrm{O} 157$ by PCR. Appl Environ Microbiol. 1999;65(7):2954-2960.

11. Gyles CL. Shiga toxin-producing Escherichia coli: an overview. J Anim Sci. 2007;85(13 Suppl):E45-62. doi:10.2527/jas.2006-508

12. Law D. Virulence factors of Escherichia coli O157 and other Shiga toxin-producing E. coli. J Appl Microbiol. 2000;88(5):729-745. doi:10.1046/j.1365-2672.2000.01031.x

13. Okrend AJG, Rose BE. "Isolation and identification of Escherichia coli 0157: H7 from meat. Revision 3, laboratory communication no. 38. FSIS, Microbiology Division." Washington, DC: US Department of Agriculture; 1989.

14. Bakhshi M, Ebrahimi F, Nazarian S, Tarverdizade Y, Sadeghi D. Identification of E. coli O157:H7 by using specific primers for $r f b E$ and $s t x 2 b$ genes. Iran South Med J. 2017;20(3):267-277.

15. Heuvelink AE, Zwartkruis-Nahuis JT, Beumer RR, de Boer E. Occurrence and survival of verocytotoxin-producing Escherichia coli $\mathrm{O} 157$ in meats obtained from retail outlets in the Netherlands. J Food Prot. 1999;62(10):1115-1122. doi:10.4315/0362-028x-62.10.1115
16. Madden RH, Espie WE, Moran L, McBride J, Scates P. Occurrence of Escherichia coli O157:H7, Listeria monocytogenes, Salmonella and Campylobacter spp. on beef carcasses in Northern Ireland. Meat Sci. 2001;58(4):343346. doi:10.1016/s0309-1740(00)00153-4

17. Rahimi E, Kazemeini HR, Salajegheh M. Escherichia coli O157:H7/NM prevalence in raw beef, camel, sheep, goat, and water buffalo meat in Fars and Khuzestan provinces, Iran. Vet Res Forum. 2012;3(1):15-17.

18. Moore JE, McCalmont $\mathrm{M}, \mathrm{Xu}$ J, et al. Prevalence of faecal pathogens in calves of racing camels (Camelus dromedarius) in the United Arab Emirates. Trop Anim Health Prod. 2002;34(4):283-287. doi:10.1023/a:1015626601014

19. El-Sayed A, Ahmed S, Awad W. Do camels (Camelus dromedarius) play an epidemiological role in the spread of Shiga Toxin producing Escherichia coli (STEC) infection? Trop Anim Health Prod. 2008;40(6):469-473. doi:10.1007/ s11250-007-9122-1

20. Hajian S, Rahimi E, Mommtaz H. A 3-year study of Escherichia coli O157: H7 in cattle, camel, sheep, goat, chicken and beef minced meat. Proceedings of the International Conference on Food Engineering and Biotechnology (IPCBEE'11); 2011.

21. Chapman PA, Siddons CA, Gerdan Malo AT, Harkin MA. A 1-year study of Escherichia coli O157 in cattle, sheep, pigs and poultry. Epidemiol Infect. 1997;119(2):245-250. doi:10.1017/s0950268897007826

22. Caprioli A, Morabito S, Brugere H, Oswald E. Enterohaemorrhagic Escherichia coli: emerging issues on virulence and modes of transmission. Vet Res. 2005;36(3):289-311. doi:10.1051/vetres:2005002

23. Rahimi E, Momtaz H, Hemmatzadeh F. The prevalence of Escherichia coli O157:H7, Listeria monocytogenes and Campylobacter spp. on bovine carcasses in Isfahan, Iran. Iran J Vet Res. 2008;9(4):365-370. doi:10.22099/ ijvr.2008.2620

24. Shekarforoush S, Pourbakhsh A, Tahamtan Y. PCR detection of Escherichia coli O157:H7 directed from slaughtered cattle in Shiraz, Iran. Arch Razi Inst. 2006;61(1):1-6. doi:10.22092/ari.2006.103720

25. Adzitey F, Huda N. Listeria monocytogenes in foods: incidences and possible control measures. Afr J Microbiol Res. 2010;4(25):2848-2855.

26. Blanco M, Blanco JE, Blanco J, et al. Prevalence and characteristics of Escherichia coli serotype O157:H7 and other verotoxin-producing $E$. coli in healthy cattle. Epidemiol Infect. 1996;117(2):251-257. doi:10.1017/ s0950268800001424

27. Aslantaş O, Erdoğan S, Cantekin Z, Gülaçti I, Evrendilek GA. Isolation and characterization of verocytotoxinproducing Escherichia coli O157 from Turkish cattle. Int J Food Microbiol. 2006;106(3):338-342. doi:10.1016/j. ijfoodmicro.2005.08.005

28. Islam MA, Mondol AS, de Boer E, et al. Prevalence and genetic characterization of Shiga toxin-producing Escherichia coli isolates from slaughtered animals in Bangladesh. Appl Environ Microbiol. 2008;74(17):54145421. doi:10.1128/aem.00854-08

29. Byrne CM, Erol I, Call JE, et al. Characterization of Escherichia coli O157:H7 from downer and healthy 
dairy cattle in the upper Midwest region of the United States. Appl Environ Microbiol. 2003;69(8):4683-4688. doi:10.1128/aem.69.8.4683-4688.2003

30. Elder RO, Keen JE, Siragusa GR, Barkocy-Gallagher GA, Koohmaraie M, Laegreid WW. Correlation of enterohemorrhagic Escherichia coli O157 prevalence in feces, hides, and carcasses of beef cattle during processing. Proc Natl Acad Sci U S A. 2000;97(7):2999-3003. doi:10.1073/pnas.060024897

31. Fantelli K, Stephan R. Prevalence and characteristics of shigatoxin-producing Escherichia coli and Listeria monocytogenes strains isolated from minced meat in Switzerland. Int J Food Microbiol. 2001;70(1-2):63-69. doi:10.1016/s0168-1605(01)00515-3

32. Chinen I, Tanaro JD, Miliwebsky E, et al. Isolation and characterization of Escherichia coli O157:H7 from retail meats in Argentina. J Food Prot. 2001;64(9):1346-1351. doi:10.4315/0362-028x-64.9.1346

33. Conedera G, Marangon S, Chapman PA, Zuin A, Caprioli A. Atypical strains of verocytotoxin-producing Escherichia coli $\mathrm{O} 157$ in beef cattle at slaughter in Veneto region, Italy. Zentralbl Veterinarmed B. 1997;44(5):301-306. doi:10.1111/j.1439-0450.1997.tb00977.x

34. Aktan I, Woodward MJ, La Ragione RM. Interaction between attaching-effacing Escherichia coli O26:K60 and O157:H7 in young lambs. Res Vet Sci. 2009;87(1):13-15. doi:10.1016/j.rvsc.2008.11.006

35. Shekarforoush S, Tahamtan Y, Pourbakhsh A. Detection and frequency of Stx2 gene in Escherichia coli $\mathrm{O} 157$ and O157:H7 strains isolated from sheep carcasses in ShirazIran. Pak J Biol Sci. 2008;11(8):1085-1092. doi:10.3923/ pjbs.2008.1085.1092

36. Hiko A, Asrat D, Zewde G. Occurrence of Escherichia coli O157:H7 in retail raw meat products in Ethiopia. J Infect Dev Ctries. 2008;2(5):389-393. doi:10.3855/jidc.203

37. Franco A, Lovari S, Cordaro G, et al. Prevalence and concentration of verotoxigenic Escherichia coli O157:H7 in adult sheep at slaughter from Italy. Zoonoses Public Health. 2009;56(5):215-220. doi:10.1111/j.1863-2378.2008.01188.x

38. Battisti A, Lovari S, Franco A, et al. Prevalence of Escherichia coli $\mathrm{O} 157$ in lambs at slaughter in Rome, central Italy. Epidemiol Infect. 2006;134(2):415-419. doi:10.1017/ s0950268805005236

39. Phillips D, Jordan D, Morris S, Jenson I, Sumner J. Microbiological quality of Australian sheep meat in 2004. Meat Sci. 2006;74(2):261-266. doi:10.1016/j. meatsci.2006.03.017

40. Duffy EA, Belk KE, Sofos JN, et al. Microbial contamination occurring on lamb carcasses processed in the United States. J Food Prot. 2001;64(4):503-508. doi:10.4315/0362028x-64.4.503

41. Hancock DD, Besser TE, Rice DH, Ebel ED, Herriott DE, Carpenter LV. Multiple sources of Escherichia coli O157 in feedlots and dairy farms in the northwestern USA. Prev Vet Med. 1998;35(1):11-19. doi:10.1016/s0167-5877(98)000506

42. Van Donkersgoed J, Graham T, Gannon V. The prevalence of verotoxins, Escherichia coli O157:H7, and Salmonella in the feces and rumen of cattle at processing. Can Vet J. 1999;40(5):332-338.

43. Shekarforoush S, Tahamtan Y, Pourbakhsh A. Detection and frequency of Stx2 gene in Escherichia coli O157 and O157:H7 strains isolated from sheep carcasses in ShirazIran. Pak J Biol Sci. 2008;11(8):1085-1092. doi:10.3923/ pjbs.2008.1085.1092

44. Khatami F, Heidari M, Khatami M. Rapid detection of Escherichia coli O157: H7 by fluorescent amplificationbased specific hybridization (FLASH) PCR. Iran Red Crescent Med J. 2012;14(9):594-598.

45. Mousavi SL, Rasooli I, Nazarian S, Amani J. Simultaneous detection of Escherichia coli O157: H7, toxigenic Vibrio cholerae, and Salmonella typhimurium by multiplex PCR. Iran J Clinic Infect Dis. 2009;4(2):97-103. 